\title{
Behavior Change Techniques Included in Reports of Social Media Interventions for Promoting Health Behaviors in Adults: Content Analysis Within a Systematic Review
}

Rosiane Simeon ${ }^{1}$, MD, MPH; Omar Dewidar ${ }^{1,2}$, HBsc; Jessica Trawin ${ }^{1}$, BSocSci; Stephanie Duench ${ }^{3}$, MPH; Heather Manson $^{4}$, MD, PhD; Jordi Pardo Pardo ${ }^{5}$, BCom; Jennifer Petkovic ${ }^{1}$, PhD; Janet Hatcher Roberts ${ }^{1,2}$, MSc; Peter Tugwell ${ }^{1,2,6,7}$, MD, PhD; Manosila Yoganathan ${ }^{1}$, BA, MA; Justin Presseau ${ }^{2,7,8}$, PhD; Vivian Welch ${ }^{1,2}, \mathrm{PhD}$

\footnotetext{
${ }^{1}$ Bruyère Research Institute, University of Ottawa, Ottawa, ON, Canada

${ }^{2}$ Faculty of Medicine, School of Epidemiology and Public Health, University of Ottawa, Ottawa, ON, Canada

${ }^{3}$ Department of Population Medicine, University of Guelph, Guelph, ON, Canada

${ }^{4}$ Dalla Lana School of Public Health, University of Toronto, Toronto, ON, Canada

${ }^{5}$ Cochrane Musculoskeletal Group, Ottawa Hospital Research Institute, Ottawa, ON, Canada

${ }^{6}$ Department of Medicine, Faculty of Medicine, University of Ottawa, Ottawa, ON, Canada

${ }^{7}$ Clinical Epidemiology Program, Ottawa Health Research Institute, Ottawa, ON, Canada

${ }^{8}$ School of Psychology, Faculty of Social Sciences, University of Ottawa, Ottawa, ON, Canada
}

\section{Corresponding Author:}

Rosiane Simeon, MD, MPH

Bruyère Research Institute

University of Ottawa

85 Primrose Ave

Ottawa, ON

Canada

Phone: 16138181154

Email: rsime006@uottawa.ca

\begin{abstract}
Background: Social media are an increasingly commonly used platform for delivering health promotion interventions. Although recent research has focused on the effectiveness of social media interventions for health promotion, very little is known about the optimal content within such interventions, and the active ingredients to promote health behavior change using social media are not clear. Identifying which behavior change techniques (BCTs) are reported may help to clarify the content of interventions using a generalizable terminology that may facilitate future intervention development.

Objective: This study aimed to identify which BCTs are reported in social media interventions for promoting health behavior change in adults.

Methods: We included 71 studies conducted with adult participants (aged $\geq 18$ years) and for which social media intervention was considered interactive in a Cochrane review of the effectiveness of such interventions. We developed a coding manual informed by the Behavior Change Technique Taxonomy version 1 (BCTTv1) to identify BCTs in the included studies. We identified BCTs in all study arms (including control) and described BCTs in the group and self-directed components of studies. We characterized the dose of delivery for each BCT by low and high intensity. We used descriptive analyses to characterize the reported BCTs.
\end{abstract}

Results: Our data consisted of 71 studies published from 2001 to 2017, mainly conducted in high-income countries ( $\mathrm{n}=65$ ). Most studies ( $\mathrm{n}=31$ ) used tailored, interactive websites to deliver the intervention; Facebook was the most used mainstream platform. In developing our coding manual, we adapted some BCTTv1 instructions to better capture unique nuances of how BCTs were operationalized in social media with respect to likes, retweets, smiles, congratulations, and badges. Social support (unspecified), instruction on how to perform the behavior, and credible source were most frequently identified BCTs in intervention arms of studies and group-delivery settings, whereas instruction on how to perform the behavior was most commonly applied in self-directed components of studies, control arms, and individual participant settings. Instruction on how to perform the behavior was also the most frequently reported BCT in both intervention and control arms simultaneously. Instruction on how to perform the behavior, 
social support (unspecified), self-monitoring of behavior, information about health consequences, and credible source were identified in the top 5 BCTs delivered with the highest intensity.

Conclusions: This study within a review provides a detailed description of the BCTs and their dose to promote behavior change in web-based, interactive social media interventions. Clarifying active ingredients in social media interventions and the intensity of their delivery may help to develop future interventions that can more clearly build upon the existing evidence.

(J Med Internet Res 2020;22(6):e16002) doi: 10.2196/16002

\section{KEYWORDS}

health behavior; taxonomy; social media; health promotion; public health

\section{Introduction}

\section{Background}

With more than 4 billion users worldwide and a projected yearly growth of $7 \%$ [1], the internet has become a central means of delivering health promotion interventions [2,3]. In particular, the advent and widespread use of social media have fostered a novel setting in which to deliver public health and health equity-oriented interventions [2,3]. These interventions greatly differ in their health aims, including HIV testing [4], mental health [5], physical activity [6], smoking cessation [7], and vaccination [8]. Social media can be characterized as consisting of "activities, practices, and behaviors among communities of people who gather online to share information, knowledge, and opinions using conversational media...that make it possible to create and easily transmit content in the form of words, pictures, videos, and audios" [9]. A primary goal of these social media interactions in health promotion is to change health behavior.

Interactions among participants in web-enabled interventions can lead to better health outcomes [10,11]. The past decade of research suggests that social media interventions may be effective in promoting health behavior change [12,13]. Earlier research has highlighted the need to improve the assessment of the design, implementation, and effectiveness of health promotion interventions delivered through social network technologies [14]. The findings from a recent review have revealed the diversity of social media features used in health-focused interventions delivered through the internet [15]. These features support several functions, including identity representation, peer grouping, and web-based social networking [15]. However, it is currently unclear which specific techniques are delivered within social media interventions, that is, which active ingredients are leveraged to promote behavior change in this new medium [11,12]. The active ingredient of an intervention that aims to change behavior can be defined as a behavior change technique (BCT), which consists of "an observable, replicable, and irreducible component of an intervention designed to alter or redirect causal processes that regulate behaviour" [16]. It is, therefore, important to describe the content of interventions delivered in social media and unpack their active ingredients to determine (1) what is actually being delivered in both intervention and control groups, (2) gaps and opportunities to consider integrating underrepresented BCTs, and (3) if this delivery mode of social media presents new BCTs or novel ways of operationalizing BCTs. Using a shared language to describe the intervention content, including which BCTs are used and how they are employed within an intervention, can help elucidate the development of future effective interventions.

Identification of BCTs using an agreed taxonomy ensures consistent comparison of techniques across studies, building toward a cumulative evidence base for informing terminology and for chartering the active ingredients of social media interventions. The Behavior Change Technique Taxonomy version 1 (BCTTv1) was developed to identify such active ingredients and to characterize the components of strategies that aim to change behavior [16-18]. The BCTTv1 with its 93 individual BCTs grouped into 16 categories [16] provides a standardized approach to classifying the content of health promotion interventions that involve behavior change. The taxonomy has been used extensively to clarify the active ingredients of health behavior change interventions in systematic reviews across several settings [19-21]. In addition, the effectiveness of health behavior change interventions in other areas has been shown to be associated with the inclusion of particular BCTs [22-24]. The findings from a systematic review that assessed the behavioral mechanisms of social media interventions on adolescent diet suggested that BCTs such as goal setting and self-monitoring of behavior may have a positive impact on changing dietary habits in adolescents [25]. However, the authors highlight the need to improve the description of BCTs delivered in social media interventions [25].

\section{Objectives}

In this study within a review (SWAR) [26], we aimed to gain a better understanding of the active ingredients of social media interventions by identifying and describing BCTs and assessing the applicability of the BCT framework to studies considered for a Cochrane review of the effectiveness of interactive social media interventions [27].

\section{Methods}

\section{Identification of Studies}

The details of the systematic review methods, including the search strategy, are available in our published protocol [27]. We searched the following major electronic databases: Cochrane Central Register of Controlled Trials (CENTRAL), Medical Literature Analysis and Retrieval System Online, or MEDLARS Online (MEDLINE), EMBASE, Cumulative Index to Nursing and Allied Health Literature (CINAHL), and PsycINFO. We also conducted a focused search for unpublished studies or reports within Google Scholar and Web of Science. The search was also extended to websites of public health governmental 
and nongovernmental organizations, such as the Public Health Agency of Canada, the World Health Organization (WHO), and international development agencies such as the Asian Development Bank and the Inter - American Development Bank. Clinical trial registries and the WHO International Clinical Trials Registry Platform were also searched for relevant studies. We also searched the reference lists of the included studies. Multimedia Appendix 1 provides a sample of the search strategy and results from MEDLINE. In brief, we included studies focused on individuals from the general population who were aged $\geq 18$ years with no limitations on their health status. We only included social media interventions that allowed two-way communication and interaction between and among participants. Some examples consisted of interventions supported through major (as of 2019) social media outlets, such as Facebook, Instagram, Twitter, and YouTube. However, interventions implemented through these platforms had to allow peer interaction to be considered in this review.

Study comparators included usual care, no intervention, or an active comparison (eg, one type of social media compared with another). The primary outcomes included validated measures of health-related behaviors, physical health, well-being, and psychological health. Studies were not excluded based on the outcome. The literature search was limited to studies that were published between January 2001 and March 2017 as most of the commonly used social media platforms were developed in 2001 or later (eg, Facebook and Twitter), and our overview showed no earlier studies using these (currently) widely used social media platforms [3]. The types of included studies consisted of randomized controlled trials (RCTs), controlled before-and-after studies, interrupted time series, and RCTs with stepped-wedge designs.

We excluded interventions that used one-way communication or one-to-one communication between a user and practitioner. For example, we excluded studies that assessed mobile health apps (eg, apps that track clinical information with contact between an individual and their health care provider) and studies with content that is transmitted unidirectionally (eg, text message reminder interventions in which the recipient is unable to reply and podcasts in which health information is provided with no opportunity for two-way communication) or which only allows for comments without sharing functionality, such as blogs. We also excluded studies that assessed web-based interventions that are based on the exchange between a single care provider and an individual participant, such as web-based cognitive behavioral therapy. Advertisements on social media (eg, Facebook) without interactive functionality and virtual gaming interventions were also excluded.

\section{Coding and Analysis Strategies}

For each eligible study, 2 trained coders (JT and RS) used BCTTv1 as a basis for coding BCTs. Coders completed BCTTv1 training and met the requirements for accurate and reliable coding. Following training, coders calibrated their coding by independently coding 3 included studies to resolve any initial discrepancies and to inform the development of a contextualized coding manual to supplement the BCTTV1. This was an iterative process to adapt the instructions if needed, which were applied to previously coded and future studies for testing. We developed a coding manual and identified any BCTs that were unique to social media. Multimedia Appendix 2 provides more details on the coding and analysis strategies related to this review.

We also distinguished between low- and high-intensity use to allow a balanced characterization of BCTs in interventions. In this review, we defined low-intensity BCT delivery as a given BCT delivered using one modality at one time. We coded high-intensity BCT delivery as a given BCT delivered more than once using the same or different modalities. Multimedia Appendix 2 provides examples of BCT statements coded as high or low intensity.

The titles of the included studies were entered in an Excel sheet, which contained all 93 BCTs organized under their respective categories. Our coding process captured the distribution of BCTs in interactive social media and self-directed components of the included studies. Interactive social media were defined as two-way communication and interaction between and among participants. Self-directed activities consisted of those carried out by participants outside of social media, such as tracking steps in a diary or using a pedometer. BCTs were extracted in both intervention and control arms in reported papers, appendices, websites, and other references indicated by the authors. We also recorded BCTs applied to participants in a group and individual participants. An interrater reliability score of kappa value 0.60 was used before starting to code [25]. Reviewers convened weekly to reconcile coding discrepancies. A third researcher ( $\mathrm{J}$ Presseau) was consulted when discrepancies could not be resolved. Frequency counts were performed separately to quantify the categories of BCTs recorded and the intensity with which these were applied. A descriptive analysis was conducted on the identification and application of BCTs in interactive social media interventions.

\section{Results}

\section{Characteristics of the Included Studies}

Studies were identified using the search strategy specified in the systematic review protocol [27]. Our team screened more than 25,000 records and assessed 282 full-text studies for eligibility criteria. After applying the eligibility criteria, 71 studies were retained eligible for analysis. The majority of the studies consisted of RCTs (60 studies). As shown in Table 1, the studies reviewed were mainly conducted in high-income countries, which hosted $92 \%(65 / 71)$ of the interventions. Only 5 interventions were conducted in upper-middle-income countries. There was only 1 study identified in lower-middle-income countries. 
Table 1. Summary of characteristics of included studies $(\mathrm{N}=71)$.

\begin{tabular}{|c|c|}
\hline Study characteristics & Value, $\mathrm{n}(\%)$ \\
\hline \multicolumn{2}{|l|}{ Country } \\
\hline High-income countries & $65(92)$ \\
\hline Upper-middle-income countries & $5(7)$ \\
\hline Lower-middle-income countries & $1(1)$ \\
\hline \multicolumn{2}{|l|}{ Study design } \\
\hline $\mathrm{RCT}^{\mathrm{a}}$ & $60(85)$ \\
\hline Non-RCT & $11(15)$ \\
\hline \multicolumn{2}{|l|}{ Types of social media } \\
\hline Tailored interactive website only & $31(44)$ \\
\hline Facebook only & $23(32)$ \\
\hline Tailored interactive website and other social media components (Facebook and interactive apps) & $13(18)$ \\
\hline Twitter or WhatsApp or WeChat & $3(4)$ \\
\hline Twitter and other social media components & $1(1)$ \\
\hline \multicolumn{2}{|l|}{ Types of outcomes ${ }^{b}$} \\
\hline Health-related behaviors & $40(56)$ \\
\hline Physical health & $25(35)$ \\
\hline Well-being & $11(15)$ \\
\hline Psychological health & $8(11)$ \\
\hline
\end{tabular}

${ }^{\mathrm{a}} \mathrm{RCT}$ : randomized controlled trial.

${ }^{\mathrm{b}}$ More than one outcome per study.

Interactive social media attributes were identified in both the experimental and control arms of the included studies. In studies with active comparators, study arms were distinguished by changing the intensity of BCTs delivered [28,29], varying web-based social interactivity [6,30], or applying different BCTs in each arm [31,32]. The authors used a variety of interactive platforms to deliver interventions. The types of social media reported were distributed as follows: tailored, interactive websites (31 studies); Facebook only (23 studies); and a combination of tailored websites and other social media components (13 studies). Although not the focus of this review, self-directed strategies used in the intervention arms of the studies were noted. These included sharing informational and educational materials through means such as email [33-35] and video recordings [36,37]. Participants also had access to noninteractive aids such as pedometers [38,39] and used text messages [40,41] and personal diaries [42] to support their offline activities.

The included studies cover a variety of population groups, including college students [43], men who have sex with men [44], parents [45], patients with chronic diseases [46,47], and pregnant women $[42,48]$.

We classified the outcomes of interest for the systematic review into 4 main categories: (1) health-related behaviors, (2) physical health, (3) well-being, and (4) psychological health. Health-related behaviors and physical health were the most reported outcomes and were identified in 40 and 25 studies, respectively. Health-related behaviors referred to the activities or practices taken by an individual, which either enhanced or deteriorated their health. It included measures such as physical activity [6,30,32,33,38,39,41,43,46,47,49-67], diet/nutrition $[47,49,52,54,56,58,59,66,68,69]$, screening/testing [35,44,70-72], smoking [7,73-77], and medication adherence $[45,78,79]$. Physical health was used to describe any physiological measure such as BMI $[32,41,56,58,63,67]$ and weight $[38,40,48-50,52,59,65-67,69,80-84]$ but not biochemical markers of physiological health.

Well-being and psychological health were reported in 11 and 8 studies, respectively. Well-being was used to classify measures of quality of life $[46,50,57,59,61,68,85]$, whereas psychological health was used to classify measures of psychological functioning, including depression [47,49,57,86,87], stress/distress $[49,68,88]$, and anxiety $[49,86]$.

\section{Capturing Behavior Change Techniques Unique to Social Media}

As shown in the examples in Table 2, in identifying BCTs across studies, 3 nuanced operationalizations of existing BCTs emerged that did not fit neatly within the existing taxonomy specifications without losing content. Our new instructions allowed us to capture overt endorsement and virtual rewards noted in specific interventions [67,89]. Overt endorsement consists of open approval of a message by participants, and it can be observed in behaviors such as forwarding emails and comments, likes, and retweets on Facebook and Twitter [47,48]. Virtual rewards consist of a system that allows collecting prizes in the form of 
smiles, congratulations, badges, virtual gifts, or stars to encourage participants in their progress toward achieving their goals $[47,48]$.

Virtual rewards (by design), although in principle consistent with the rewards (behavior) BCT, have a level of nuance within the web-based environment that we decided it was worth making an explicit distinction in coding instructions for that BCT.
Namely, we coded all statements that described overt endorsement such as likes, smiles, virtual gifts, Twitter posts, and public post on profile page wall as social support (unspecified) when these statements came from participants themselves in a natural manner. However, we coded these same statements as nonspecific reward or social reward when they were embedded in the design of the intervention to acknowledge the achievement of participants.

Table 2. Application of newly created rules for capturing virtual rewards.

\begin{tabular}{|c|c|c|}
\hline New instructions & Representative example of coded statements & $\begin{array}{l}\text { Behavior change technique } \\
\text { taxonomy version } 1 \text { code }\end{array}$ \\
\hline $\begin{array}{l}\text { Overt endorsement (from partici- } \\
\text { pants) }\end{array}$ & $\begin{array}{l}\text { "Participants in this intervention were free to post their own relevant messages } \\
\text { through videos, text, pictures and so on. They could engage in relevant discus- } \\
\text { sions via commenting." [90] }\end{array}$ & Social support (unspecified) \\
\hline Virtual rewards (by design) & $\begin{array}{l}\text { "It included gamification features, such as awards for individual and team step- } \\
\text { logging and step-count achievements and the ability to send virtual gifts to } \\
\text { teammates." [61] }\end{array}$ & Social reward \\
\hline Virtual rewards (by design) & $\begin{array}{l}\text { "Engagement was rewarded in the intervention group with points, badges and } \\
\text { gradual revealing of graphic-level images and other virtual elements." [89] }\end{array}$ & Nonspecific reward \\
\hline
\end{tabular}

\section{Identification of Behavior Change Techniques in the Studies}

We identified 46 out of 93 techniques from the BCTTv1 across the 71 included studies, which are displayed in Multimedia Appendix 3. BCTs were mainly reported in the Methods section of the studies (68 studies). We also identified BCTs from additional sources, such as protocols (11 studies), study appendices (4 studies), and author-identified companion papers (4 studies).

\section{Behavior Change Techniques Applied in Interactive Social Media and Self-Directed Components}

More than 55\% (26/46) of the BCTs identified were applied in the interactive social media component of interventions (two-way communication and interaction between and among participants). The top 15 BCTs applied across interactive social media and self-directed components of studies (one-way communication or no social interaction) are displayed in Table 3. As expected, social support (unspecified) was the most common BCT identified in interactive social media components (51 studies) [6-8,28,30,32,35,36,38,39,41,44-47,50-55,57,59,61, 63-66,69-73,75,77-80,82,83,85,87-95], followed by instruction onhow to perform the behavior (21 studies) [28,36,37, 46-49,52,61,64,68,72,76,77,82,84,85,91,95-97], credible source (16 studies) [7,28,30,35,36,39,47,55,64,69,72,76,79,94,95,97], social comparison (8 studies) [36,43,48,54,61,65,80,82], and information about health consequences (8 studies) $[28,43,64,68,72,83,90,95]$. On the other hand, instruction on how to perform the behavior was the most commonly identified BCT in the self-directed component of interventions (39 studies) [6-8,30,32,34,38-41,43-45,50,51,53,55-60,62,65-67,69,71,74,75,79-81, $83,86,87,89,93,94]$, followed by self-monitoring of behavior (32 studies) [6,30,32,33,38-41,45,46,48,50,51,54-58,60,63-66, $69,76,79,81-84,92,98]$, credible source (29 studies) $[8,32,34,38,41,44,45,48,50,53,56,58,59,62,65,66,68$, $74,75,77,80-82,85,88,90,92,93,96]$, goal-setting behavior $(25$ studies) [6,30,32,38,39,41,48,50,51,54,55,57-60,65-67,74,75, $81-84,98]$, and adding objects to the environment (24 studies) [30,32,38-41,46,48-51,56-61,66,70,80,81,83,93,98]. 
Table 3. Top 15 behavior change techniques captured in the components of interventions $(n=71)$.

\begin{tabular}{|c|c|c|}
\hline Behavior change techniques & Social media, $\mathrm{n}^{\mathrm{a}}(\%)$ & Self-directed, $\mathrm{n}^{\mathrm{a}}(\%)$ \\
\hline 1.1 Goal setting (behavior) & $7(10)$ & $25(35)$ \\
\hline 1.2 Problem solving & $6(8)$ & $13(18)$ \\
\hline 1.4 Action planning & $\mathrm{N} / \mathrm{A}^{\mathrm{b}}$ & $19(27)$ \\
\hline 2.2 Feedback on behavior & $3(4)$ & $19(27)$ \\
\hline 2.3 Self-monitoring of behavior & $5(7)$ & $32(45)$ \\
\hline 2.4 Self-monitoring of outcome(s) of behavior & $2(3)$ & N/A \\
\hline 3.1 Social support (unspecified) & $51(72)$ & $12(17)$ \\
\hline 3.2 Social support (practical) & $7(10)$ & $17(24)$ \\
\hline 3.3 Social support (emotional) & $3(4)$ & N/A \\
\hline 4.1 Instruction on how to perform the behavior & $21(30)$ & $39(55)$ \\
\hline 5.1 Information about health consequences & $8(11)$ & $17(24)$ \\
\hline 6.1 Demonstration of the behavior & $7(10)$ & $11(15)$ \\
\hline 6.2 Social comparison & $8(11)$ & N/A \\
\hline 7.1 Prompts/cues & $7(10)$ & $21(30)$ \\
\hline 8.7 Graded tasks & N/A & $14(20)$ \\
\hline 9.1 Credible source & $16(23)$ & $29(41)$ \\
\hline 11.1 Pharmacological support & N/A & $9(13)$ \\
\hline 12.2 Restructuring the social environment & $5(7)$ & N/A \\
\hline 12.5 Adding objects to the environment & N/A & $24(34)$ \\
\hline
\end{tabular}

${ }^{\mathrm{a} B e h a v i o r}$ change techniques applied in interactive social media components and self-directed components.

${ }^{\mathrm{b}} \mathrm{N} / \mathrm{A}$ : not applicable.

\section{Behavior Change Techniques Applied in the Intervention and Control Arms}

The top 5 BCTs applied in intervention arms of the included studies: social support (unspecified; 56 studies) [6-8,28,30,32-36,38-41,44-47,52-62,64-66,69,70,72,73,75,77-83,85-95,97], instruction on how to perform the behavior (37 studies) [8,28,36,37,40,44-48,52,53,56-58,61,64,67,68,72,75,77,79,81-87,89,91,93-97], credible source (35 studies) [7,8,28,34-36,39,41,44,45,47, 48,53,56,58,59,62,64,65,68,69,72,75,77,79,81,82,85,88,92-97], self-monitoring of behavior (25 studies) [6,32,39,40,45-48, $56-58,61,64,65,69,76,78-84,88,92]$, and prompts/cues (24 studies) $[33,39-41,43,47,48,52,55,56,58,61,64,65,69,73,78,79$, $81,82,89,92,93,97]$. The content of the control arms was generally reported as usual care. Only 9 different BCTs were uniquely applied in the control arms of the studies. Instruction on how to perform the behavior, social support (unspecified), and information about health consequences constituted the most commonly applied BCTs in control arms only and were identified in 8 [7,29,34,38,39,41,59,66], 3 [50,51,63], and 2 $[38,63]$ studies, respectively. The top 15 BCTs applied to the intervention and control arms of the included studies are displayed in Table 4.

Across the included studies, 14 of the top 15 BCTs applied in intervention arms only were also used in studies with BCTs applied in both arms. The exception was social comparison, which was solely identified in the intervention arms of 11 studies $[32,33,36,43,48,54,58,61,65,80,82]$. As shown in Table 4, the ranking of BCTs also changed with the simultaneous application of BCTs in both study arms in comparison with application in intervention arms only. 
Table 4. Top 15 behavior change techniques in the study arms $(n=71)$.

\begin{tabular}{|c|c|c|c|}
\hline Behavior change techniques & Intervention, $\mathrm{n}^{\mathrm{a}}(\%)$ & Control, $\mathrm{n}^{\mathrm{a}}(\%)$ & Intervention and control, $\mathrm{n}^{\mathrm{a}}(\%)$ \\
\hline 1.1 Goal setting (behavior) & $19(27)$ & $\mathrm{N} / \mathrm{A}^{\mathrm{b}}$ & $13(18)$ \\
\hline 1.2 Problem solving & $13(18)$ & $1(1)$ & $5(7)$ \\
\hline 1.4 Action planning & $14(20)$ & $1(1)$ & $6(8)$ \\
\hline 2.2 Feedback on behavior & $16(23)$ & N/A & $6(8)$ \\
\hline 2.3 Self-monitoring of behavior & $25(35)$ & $1(1)$ & $11(15)$ \\
\hline 3.1 Social support (unspecified) & $56(79)$ & $3(4)$ & $4(6)$ \\
\hline 3.2 Social support (practical) & $18(25)$ & N/A & $6(8)$ \\
\hline 4.1 Instruction on how to perform the behavior & $37(52)$ & $8(11)$ & $15(21)$ \\
\hline 5.1 Information about health consequences & $15(21)$ & $2(3)$ & $8(11)$ \\
\hline 6.1 Demonstration of the behavior & $14(20)$ & N/A & $4(6)$ \\
\hline 6.2 Social comparison & $11(25)$ & N/A & N/A \\
\hline 7.1 Prompts/cues & $21(30)$ & N/A & $7(10)$ \\
\hline 8.7 Graded tasks & $9(13)$ & N/A & $5(7)$ \\
\hline 9.1 Credible source & $35(49)$ & $1(1)$ & $9(13)$ \\
\hline 11.1 Pharmacological support & N/A & N/A & $4(6)$ \\
\hline 11.3 Conserving mental resources & N/A & $1(1)$ & N/A \\
\hline 12.5 Adding objects to the environment & $13(18)$ & N/A & $11(15)$ \\
\hline 13.2 Framing/reframing & N/A & $1(1)$ & N/A \\
\hline
\end{tabular}

${ }^{a}$ Behavior change techniques applied in intervention arms only, control arms, and intervention and control arms simultaneously.

${ }^{\mathrm{b}} \mathrm{N} / \mathrm{A}$ : not applicable.

\section{Behavior Change Techniques Applied to Group and Individual Participants}

Social support (unspecified) was the most commonly applied BCTs to a group of participants (50 studies) $[6-8,30,32,33,36,38,39,41,44-46,50-61,63-66,69-73,75-78,80,82,83,85-87,90-95]$. It was then followed by instruction on how to perform the behavior $\quad(24 \quad$ studies $) \quad[36,37,44,45,48,52,53,55-58$, $62,64,67,72,76,82,84,85,87,93,95-97]$, credible source (23 studies) [7,30,35,36,39,44,45,47,53,55,56,58,64,69,72,75,77, $79,85,90,94,95,97]$, demonstration of the behavior (12 studies) $[6,36,52,53,55,56,58,62,64,76,93,94]$, and social support practical (11 studies) [7,32,33,39,48,52,53,58,68,72,76]. When
BCTs were applied to individuals, instruction on how to perform the behavior was the most frequent (36 studies) $[6-8,28,30,32,34,38-41,43,46,47,49-51,59-61,65,66,68,69,71,74,75,77,79-81$, $83,86,89,91,94]$, followed by self-monitoring of behavior $(34$ studies) [6,30,32,33,38-41,46-48,50,51,54-58,60,61,63,65,66, 69,76,78-83,88,92,98], goal-setting behavior (30 studies) $[6,30,32,38,39,41,46-48,50,51,54,55,57-60,65-67,74-77$, $81-84,86,98]$, adding objects to the environment (24 studies) [30,32,38-41,46,48-51,56-61,66,70,80,81,83,93,98], and credible source (22 studies) [8,28,32,34,38,41,48,50,59, $62,65,66,68,74,77,80-82,88,92,93,96]$. Table 5 shows the most frequent BCTs applied to group and individual participants. 
Table 5. Top 15 behavior change techniques in participant settings $(n=71)$.

\begin{tabular}{|c|c|c|}
\hline Behavior change techniques & Group setting, $\mathrm{n}^{\mathrm{a}}(\%)$ & Individual setting, $\mathrm{n}^{\mathrm{a}}(\%)$ \\
\hline 1.1 Goal setting (behavior) & $\mathrm{N} / \mathrm{A}^{\mathrm{b}}$ & $30(42)$ \\
\hline 1.2 Problem solving & $5(7)$ & $14(20)$ \\
\hline 1.4 Action planning & $5(7)$ & $16(23)$ \\
\hline 1.5 Review behavior goal(s) & N/A & $10(14)$ \\
\hline 2.2 Feedback on behavior & N/A & $19(27)$ \\
\hline 2.3 Self-monitoring of behavior & $3(4)$ & $34(48)$ \\
\hline 2.8 Feedback on outcome(s) of behavior & N/A & $7(10)$ \\
\hline 3.1 Social support (unspecified) & $50(70)$ & $13(18)$ \\
\hline 3.2 Social support (practical) & $11(15)$ & $13(18)$ \\
\hline 3.3 Social support (emotional) & $3(4)$ & N/A \\
\hline 4.1 Instruction on how to perform the behavior & $24(34)$ & $36(51)$ \\
\hline 5.1 Information about health consequences & $6(8)$ & $19(27)$ \\
\hline 5.3 Information about social and environmental consequences & $3(4)$ & N/A \\
\hline 6.1 Demonstration of the behavior & $12(17)$ & N/A \\
\hline 6.2 Social comparison & $9(13)$ & N/A \\
\hline 7.1 Prompts/cues & $9(13)$ & $19(27)$ \\
\hline 8.1 Behavioral practice/rehearsal & $4(6)$ & N/A \\
\hline 8.7 Graded tasks & N/A & $13(18)$ \\
\hline 9.1 Credible source & $23(32)$ & $22(31)$ \\
\hline 12.2 Restructuring the social environment & $6(8)$ & N/A \\
\hline 12.5 Adding objects to the environment & N/A & $24(34)$ \\
\hline
\end{tabular}

${ }^{\mathrm{a}}$ Behavior change techniques applied to individuals in the group setting and individual participants.

\section{Low- and High-Intensity Use of Behavior Change Techniques}

We characterized the intensity of delivering BCTs by identifying the modalities used to expose participants to a BCT. BCTs that were delivered using at least two modalities were coded as high intensity. Participants were exposed to BCTs through interactive social media and self-directed components in intervention or control arms of the studies and in a group or individually. The top 5 BCTs that were delivered with high intensity included instruction on how to perform the behavior (35 studies)
[7,28,32,34,36-38,40,45,48,49,52,53,55-59,62,65-69,72,74,75,77,79,80,83, $85,93,95,96]$, social support (unspecified; 28 studies) [7,8,28,32-35,37,40,41,45,50,51,56,61-67,71,73-75,77,81,86], self-monitoring of behavior (16 studies) [32,50,51,54,57,58,60,63,64,66,67,69,78,82,92,96], information about health consequences (13 studies) $[7,32,34,36,38,48,50,56,59,80,81,95,96]$, and credible source (13 studies) [7,32,34,36,38,48,50,56,59,80,81,95,96]. The top 15 most frequent BCTs coded for high-intensity delivery are displayed in Table 6. 
Table 6. Top 15 behavior change techniques coded for high-intensity delivery $(\mathrm{n}=71)$.

\begin{tabular}{ll}
\hline Behavior change techniques & Value, $\mathrm{n}(\%)$ \\
\hline 1.1 Goal setting (behavior) & $10(14)$ \\
1.2 Problem solving & $5(7)$ \\
1.4 Action planning & $8(11)$ \\
1.5 Review behavior goal(s) & $3(4)$ \\
12.5 Adding objects to the environment & $8(11)$ \\
2.2 Feedback on behavior & $8(11)$ \\
2.3 Self-monitoring of behavior & $16(23)$ \\
3.1 Social support (unspecified) & $28(39)$ \\
3.2 Social support (practical) & $4(6)$ \\
4.1 Instruction on how to perform the behavior & $35(49)$ \\
5.1 Information about health consequences & $15(21)$ \\
6.1 Demonstration of the behavior & $6(8)$ \\
6.2 Social comparison & $3(4)$ \\
7.1 Prompts/cues & $3(4)$ \\
9.1 Credible source & $13(18)$ \\
\hline
\end{tabular}

\section{Discussion}

\section{Principal Findings}

We found that the BCTTv1 was applicable to studies promoting health behaviors using social media in a web-based environment. Given that all these studies focused on interactive web-based platforms, it is surprising that relatively few studies have reported leveraging the full spectrum of social comparison and social support BCTs. Furthermore, few studies have reported using BCTs that have been associated with effective behavior change in other settings (eg, goal setting and action planning) $[99,100]$.

We made 3 adaptations to the coding structure to accurately and specifically code overt endorsement and virtual rewards, which we decided to be a type of social support when provided by peers through the internet and a type of social reward when provided by intervention designers. We also developed a method for coding the intensity of BCTs, which allowed us to identify studies with more intense use of BCTs. We added to the description of some BCTs to capture these nuances of interactive social media. Kadushin [101] and Southwell [102] highlighted the potential of overt endorsement and virtual rewards in influencing individual attitudes and health-related behaviors. We also noted that these techniques were reported in other studies as a measurement of engagement with participants and reach of interventions $[67,90]$.

The interventions were mainly delivered through tailored, interactive platforms (ie, platforms developed by the research team ). At the time of conducting this research, Facebook remained the most commonly used platform among the mainstream social media outlets for intervention studies and was used either alone or in combination with other social media components. Nonetheless, this does not dismiss the popularity of other social media platforms implemented in other countries.
Social media platforms usually allow social interactions beyond geographical boundaries. We noted that none of the included studies had a global focus, that is, all were conducted within a specific country or region. In addition, with the widespread digital technologies, we expected to see more than one study from low- and middle-income countries. Resource settings [103] and research capacity [104,105] might be explored when assessing possible reasons for limited implementation internationally.

Almost all the studies used a variety of BCTs to deliver interventions through social media. The identified BCTs were applied in both the intervention and control arms of the studies. For this reason, it is essential to identify the intensity with which BCTs are applied. Identifying the intensity can help to determine if the extent of exposure makes a difference in the impact of changing behavior. Even after considering intensity, caution should still be applied when assessing the role of BCTs in changing the behavior of participants because some BCTs were applied with almost equal intensity in the control and intervention arms. This was observed for the BCT instruction on how to perform the behavior.

In addition, the content of control arms was mainly reported as usual care, with often no accompanying details on the features of such conditions. This situation makes it difficult to adequately characterize the content of control arms and warrants more analysis in attributing effectiveness to BCTs applied in intervention arms [52]. The types of BCTs applied to individuals in a group setting and those applied to individual participants varied greatly. This provides opportunities to explore which BCTs are optimal in a group setting and to identify which ones are inherently appropriate for individual activity only. Additional research can help elucidate the mechanisms of action of BCTs in interventions and further contribute to their optimal use to foster behavior change. 


\section{Limitations}

One limitation of this research is that we relied on what was reported in the source studies. We attempted to check the web-based sites, but a lot had changed since the publication of the studies in the review. Therefore, the relative paucity of some BCTs (eg, social comparison and goal setting) may be related to insufficient detail in the published papers to code these aspects of the intervention. We encourage future reports of interventions to provide screenshots or access to the version of the platform used at the time of the intervention as additional files or links. In addition, the use of validated tools such as the Consolidated Standards of Reporting Trials eHealth can help improve the description and reporting of web-based interventions, thereby facilitating their implementation and replication to improve health outcomes [106].

Future research can also contribute to better characterize BCTs applied to foster social support in interactive social media interventions. Social support (unspecified) was the most commonly applied BCT in the studies analyzed. The definition of this BCT is comprehensive enough to allow the identification of social assistance with no specific descriptors, whereas BCTs such as social support (practical) and social support (emotional) allow capturing what social assistance entails. A better characterization of social support in interventions could help to distill in what ways this particular social interaction makes a difference in the behavior of participants.

\section{Comparisons With Prior Work}

A recent review that focused on social media features in web-based interventions reported that communication in the form of forums is the most common social media feature for sustaining behavior change [15]. These results are aligned with those of this SWAR, which shows that generic social support is the most common BCT used in interactive social media interventions, which was mainly captured in interventions that use discussion forums, group activities, and other exchanges to foster mutual support among participants.

\section{Future Work}

In this study, we provide an overview of the most commonly reported BCTs applied in social media intervention studies. As social media interventions continue to increase in popularity, it may be useful in future work to assess how the presence of particular BCTs or a combination of BCTs is associated with effects on health behavior change.

\section{Conclusions}

Our newly developed coding instructions along with BCTTv1 were useful in characterizing behavior change content in social media interventions and evaluating its effectiveness. This assessment of BCTs identified nuances in the operationalization of the BCTTv1 to characterize the unique features of interactive social media interventions for health promotion. These characteristics may be considered when designing social media platforms aimed at promoting public health. Our coding could further help deconstruct the complexity of interventions that use digital technologies and provide further understanding of the role of specific BCTs on behavior change. Although other studies highlighted the effectiveness of BCTs, such as goal setting and action planning, very few of the included studies used them. Increasing the use of BCTs is known to be effective in improving social media interventions.

\section{Acknowledgments}

The authors would like to thank Tamara Rader who developed the search strategy for the systematic review with the assistance of Jordi Pardo and Manosila Yoganathan. The authors acknowledge the assistance of Alexandra Sokolovski in testing the data extraction form. RS received funding from the Bruyère Research Institute Studentship Program. PT is the Canada Research Chair of Health Equity. VW is a recipient of the Ontario Early Research Award.

\section{Authors' Contributions}

RS, VW, J Presseau, JT, and OD drafted the review. Input on the review draft was provided by HM, SD, JR, J Petkovic, MY, J Presseau, and PT. VW and J Presseau are joint senior authors.

\section{Conflicts of Interest}

None declared.

\section{Multimedia Appendix 1}

User manual for coding behavior change techniques using the Behavior Change Technique Taxonomy version 1 in social media-based health interventions.

[DOCX File, 14 KB-Multimedia Appendix 1]

\section{Multimedia Appendix 2}

Sample of search strategy and results from the Medical Literature Analysis and Retrieval System Online, or MEDLARS Online database.

[DOCX File , 41 KB-Multimedia Appendix 2] 


\section{Multimedia Appendix 3}

Distribution of behavior changing techniques captured across the 71 included studies.

[PNG File, 484 KB-Multimedia Appendix 3]

\section{References}

1. We Are Social. 2018. Digital in 2018: World's Internet Users Pass the 4 Billion Mark URL: https://wearesocial.com/blog/ 2018/01/global-digital-report-2018 [accessed 2019-05-27]

2. Bennett GG, Glasgow RE. The delivery of public health interventions via the internet: actualizing their potential. Annu Rev Public Health 2009;30:273-292. [doi: 10.1146/annurev.publhealth.031308.100235] [Medline: 19296777]

3. Welch V, Petkovic J, Pardo JP, Rader T, Tugwell P. Interactive social media interventions to promote health equity: an overview of reviews. Health Promot Chronic Dis Prev Can 2016 Apr;36(4):63-75 [FREE Full text] [doi: 10.24095/hpcdp.36.4.01] [Medline: 27077792]

4. Cao B, Gupta S, Wang J, Hightow-Weidman LB, Muessig KE, Tang W, et al. Social media interventions to promote HIV testing, linkage, adherence, and retention: systematic review and meta-analysis. J Med Internet Res 2017 Nov 24;19(11):e394 [FREE Full text] [doi: 10.2196/jmir.7997] [Medline: 29175811]

5. de Choudhury M, Kiciman E. The language of social support in social media and its effect on suicidal ideation risk. Proc Int AAAI Conf Weblogs Soc Media 2017 May;2017:32-41 [FREE Full text] [Medline: 28840079]

6. Cavallo DN, Tate DF, Ries AV, Brown JD, DeVellis RF, Ammerman AS. A social media-based physical activity intervention: a randomized controlled trial. Am J Prev Med 2012 Nov;43(5):527-532 [FREE Full text] [doi: 10.1016/j.amepre.2012.07.019] [Medline: 23079176]

7. Ramo DE, Thrul J, Chavez K, Delucchi KL, Prochaska JJ. Feasibility and quit rates of the tobacco status project: a Facebook smoking cessation intervention for young adults. J Med Internet Res 2015 Dec 31;17(12):e291 [FREE Full text] [doi: 10.2196/jmir.5209] [Medline: 26721211]

8. Glanz JM, Wagner NM, Narwaney KJ, Kraus CR, Shoup JA, Xu S, et al. Web-based social media intervention to increase vaccine acceptance: a randomized controlled trial. Pediatrics 2017 Dec;140(6):e20171117 [FREE Full text] [doi:

10.1542/peds.2017-1117] [Medline: 29109107]

9. Safko L. The Social Media Bible: Tactics, Tools, and Strategies for Business Success. Third Edition. Hoboken, New Jersey: Wiley; 2012.

10. Jones K, Baldwin KA, Lewis PR. The potential influence of a social media intervention on risky sexual behavior and Chlamydia incidence. J Community Health Nurs 2012;29(2):106-120. [doi: 10.1080/07370016.2012.670579] [Medline: 22536914]

11. Korda H, Itani Z. Harnessing social media for health promotion and behavior change. Health Promot Pract 2013 Jan;14(1):15-23. [doi: 10.1177/1524839911405850] [Medline: 21558472]

12. Maher CA, Lewis LK, Ferrar K, Marshall S, de Bourdeaudhuij I, Vandelanotte C. Are health behavior change interventions that use online social networks effective? A systematic review. J Med Internet Res 2014 Feb 14;16(2):e40 [FREE Full text] [doi: 10.2196/jmir.2952] [Medline: 24550083]

13. Naslund JA, Kim SJ, Aschbrenner KA, McCulloch LJ, Brunette MF, Dallery J, et al. Systematic review of social media interventions for smoking cessation. Addict Behav 2017 Oct;73:81-93 [FREE Full text] [doi: 10.1016/j.addbeh.2017.05.002] [Medline: 28499259]

14. Balatsoukas P, Kennedy CM, Buchan I, Powell J, Ainsworth J. The role of social network technologies in online health promotion: a narrative review of theoretical and empirical factors influencing intervention effectiveness. J Med Internet Res 2015 Jun 11;17(6):e141 [FREE Full text] [doi: 10.2196/jmir.3662] [Medline: 26068087]

15. Elaheebocus SM, Weal M, Morrison L, Yardley L. Peer-based social media features in behavior change interventions: systematic review. J Med Internet Res 2018 Feb 22;20(2):e20 [FREE Full text] [doi: 10.2196/jmir.8342] [Medline: 29472174]

16. Michie S, Richardson M, Johnston M, Abraham C, Francis J, Hardeman W, et al. The behavior change technique taxonomy (v1) of 93 hierarchically clustered techniques: building an international consensus for the reporting of behavior change interventions. Ann Behav Med 2013 Aug;46(1):81-95. [doi: 10.1007/s12160-013-9486-6] [Medline: 23512568]

17. Kok G, Gottlieb NH, Peters GY, Mullen PD, Parcel GS, Ruiter RA, et al. A taxonomy of behaviour change methods: an intervention mapping approach. Health Psychol Rev 2016 Sep;10(3):297-312 [FREE Full text] [doi: 10.1080/17437199.2015.1077155] [Medline: 26262912]

18. Nudelman G, Shiloh S. Mapping health behaviors: constructing and validating a common-sense taxonomy of health behaviors. Soc Sci Med 2015 Dec;146:1-10. [doi: 10.1016/j.socscimed.2015.10.004] [Medline: 26473449]

19. Presseau J, Ivers NM, Newham JJ, Knittle K, Danko KJ, Grimshaw JM. Using a behaviour change techniques taxonomy to identify active ingredients within trials of implementation interventions for diabetes care. Implement Sci 2015 Apr 23;10:55 [FREE Full text] [doi: 10.1186/s13012-015-0248-7] [Medline: 25900104]

20. Fulton EA, Brown KE, Kwah KL, Wild S. StopApp: using the behaviour change wheel to develop an app to increase uptake and attendance at NHS stop smoking services. Healthcare (Basel) 2016 Jun 8;4(2):e31 [FREE Full text] [doi: 10.3390/healthcare4020031] [Medline: 27417619] 
21. Michie S, West R, Sheals K, Godinho CA. Evaluating the effectiveness of behavior change techniques in health-related behavior: a scoping review of methods used. Transl Behav Med 2018 Mar 1;8(2):212-224 [FREE Full text] [doi: 10.1093/tbm/ibx019] [Medline: 29381786]

22. Albarracín D, Gillette JC, Earl AN, Glasman LR, Durantini MR, Ho M. A test of major assumptions about behavior change: a comprehensive look at the effects of passive and active HIV-prevention interventions since the beginning of the epidemic. Psychol Bull 2005 Nov;131(6):856-897 [FREE Full text] [doi: 10.1037/0033-2909.131.6.856] [Medline: 16351327]

23. Fortune N, Madden R, Almborg A. Use of a new international classification of health interventions for capturing information on health interventions relevant to people with disabilities. Int J Environ Res Public Health 2018 Jan 17;15(1):145 [FREE Full text] [doi: 10.3390/ijerph15010145] [Medline: 29342077]

24. Rothman AJ. 'Is there nothing more practical than a good theory?': why innovations and advances in health behavior change will arise if interventions are used to test and refine theory. Int J Behav Nutr Phys Act 2004 Jul 27;1(1):11 [FREE Full text] [doi: 10.1186/1479-5868-1-11] [Medline: 15279674]

25. Hsu MS, Rouf A, Allman-Farinelli M. Effectiveness and behavioral mechanisms of social media interventions for positive nutrition behaviors in adolescents: a systematic review. J Adolesc Health 2018 Nov;63(5):531-545. [doi: 10.1016/j.jadohealth.2018.06.009] [Medline: 30197198]

26. -. Education section-studies within a review (SWAR). J Evid Based Med 2012 Aug;5(3):188-189. [doi: 10.1111/j.1756-5391.2012.01193.x] [Medline: 23672229]

27. Petkovic J, Simeon R, Presseau J, Gagnon D, Hossain A, Pardo PJ. Interactive social media interventions for health behaviour change, health outcomes, and health equity in the adult population. Cochrane Database Syst Rev 2018(2):CD012932. [doi: 10.1002/14651858.CD012932]

28. Mayer AB, Harrison JA. Safe Eats: an evaluation of the use of social media for food safety education. J Food Prot 2012 Aug;75(8):1453-1463. [doi: 10.4315/0362-028X.11-551] [Medline: 22856569]

29. Schaller A, Petrowski K, Pfoertner T, Froboese I. Effectiveness of a theory-based multicomponent intervention (movement coaching) on the promotion of total and domain-specific physical activity: a randomised controlled trial in low back pain patients. BMC Musculoskelet Disord 2017 Nov 6;18(1):431 [FREE Full text] [doi: 10.1186/s12891-017-1788-6] [Medline: 29110703]

30. Richardson CR, Buis LR, Janney AW, Goodrich DE, Sen A, Hess ML, et al. An online community improves adherence in an internet-mediated walking program. Part 1: results of a randomized controlled trial. J Med Internet Res 2010 Dec

17;12(4):e71 [FREE Full text] [doi: 10.2196/jmir.1338] [Medline: 21169160]

31. Graham A. Development of the pharyngeal arches. Am J Med Genet A 2003 Jun 15;119A(3):251-256. [doi: 10.1002/ajmg.a.10980] [Medline: 12784288]

32. Rovniak LS, Kong L, Hovell MF, Ding D, Sallis JF, Ray CA, et al. Engineering online and in-person social networks for physical activity: a randomized trial. Ann Behav Med 2016 Dec;50(6):885-897 [FREE Full text] [doi: 10.1007/s12160-016-9814-8] [Medline: 27405724]

33. Zhang J, Brackbill D, Yang S, Becker J, Herbert N, Centola D. Support or competition? How online social networks increase physical activity: a randomized controlled trial. Prev Med Rep 2016 Dec;4:453-458 [FREE Full text] [doi: 10.1016/j.pmedr.2016.08.008] [Medline: 27617191]

34. O'Neil PM, Miller-Kovach K, Tuerk PW, Becker LE, Wadden TA, Fujioka K, et al. Randomized controlled trial of a nationally available weight control program tailored for adults with type 2 diabetes. Obesity (Silver Spring) 2016 Nov;24(11):2269-2277 [FREE Full text] [doi: 10.1002/oby.21616] [Medline: 27804264]

35. Hwang KO, Ottenbacher AJ, Graham AL, Thomas EJ, Street RL, Vernon SW. Online narratives and peer support for colorectal cancer screening: a pilot randomized trial. Am J Prev Med 2013 Jul;45(1):98-107. [doi: 10.1016/j.amepre.2013.02.024] [Medline: 23790994]

36. Fiks AG, Gruver RS, Bishop-Gilyard CT, Shults J, Virudachalam S, Suh AW, et al. A social media peer group for mothers to prevent obesity from infancy: the Grow2Gether randomized trial. Child Obes 2017 Oct;13(5):356-368 [FREE Full text] [doi: 10.1089/chi.2017.0042] [Medline: 28557558]

37. Laws RA, Denney-Wilson EA, Taki S, Russell CG, Zheng M, Litterbach E, et al. Key lessons and impact of the growing healthy mhealth program on milk feeding, timing of introduction of solids, and infant growth: quasi-experimental study. JMIR Mhealth Uhealth 2018 Apr 19;6(4):e78 [FREE Full text] [doi: 10.2196/mhealth.9040] [Medline: 29674313]

38. Rote AE, Klos LA, Brondino MJ, Harley AE, Swartz AM. The efficacy of a walking intervention using social media to increase physical activity: a randomized trial. J Phys Act Health 2015 Jun 16;12(Suppl 1):S18-S25. [doi:

10.1123/jpah.2014-0279] [Medline: 25599378]

39. Schneider KL, Murphy D, Ferrara C, Oleski J, Panza E, Savage C, et al. An online social network to increase walking in dog owners: a randomized trial. Med Sci Sports Exerc 2015 Mar;47(3):631-639 [FREE Full text] [doi: 10.1249/MSS.0000000000000441] [Medline: 25003777]

40. Napolitano MA, Hayes S, Bennett GG, Ives AK, Foster GD. Using Facebook and text messaging to deliver a weight loss program to college students. Obesity (Silver Spring) 2013 Jan;21(1):25-31 [FREE Full text] [doi: 10.1002/oby.20232] [Medline: 23505165] 
41. Joseph RP, Keller C, Adams MA, Ainsworth BE. Print versus a culturally-relevant Facebook and text message delivered intervention to promote physical activity in African American women: a randomized pilot trial. BMC Womens Health 2015 Mar 27;15:30 [FREE Full text] [doi: 10.1186/s12905-015-0186-1] [Medline: 25886945]

42. Linden K, Berg M, Adolfsson A, Sparud-Lundin C. Person-centred, web-based support in pregnancy and early motherhood for women with type 1 diabetes mellitus: a randomized controlled trial. Diabet Med 2018 Feb;35(2):232-241 [FREE Full text] [doi: 10.1111/dme.13552] [Medline: 29171071]

43. Al-Eisa E, Al-Rushud A, Alghadir A, Anwer S, Al-Harbi B, Al-Sughaier N, et al. Effect of motivation by 'Instagram' on adherence to physical activity among female college students. Biomed Res Int 2016;2016:1546013 [FREE Full text] [doi: 10.1155/2016/1546013] [Medline: 27034927]

44. Ko N, Hsieh C, Wang M, Lee C, Chen C, Chung A, et al. Effects of internet popular opinion leaders (iPOL) among internet-using men who have sex with men. J Med Internet Res 2013 Feb 25;15(2):e40 [FREE Full text] [doi:

10.2196/jmir.2264] [Medline: 23439583]

45. Bai G, Wang Y, Yang L, Niu W. Effectiveness of a focused, brief psychoeducation program for parents of ADHD children: improvement of medication adherence and symptoms. Neuropsychiatr Dis Treat 2015;11:2721-2735 [FREE Full text] [doi: 10.2147/NDT.S88625] [Medline: 26604761]

46. Moy ML, Collins RJ, Martinez CH, Kadri R, Roman P, Holleman RG, et al. An internet-mediated pedometer-based program improves health-related quality-of-life domains and daily step counts in COPD: a randomized controlled trial. Chest 2015 Jul;148(1):128-137 [FREE Full text] [doi: 10.1378/chest.14-1466] [Medline: 25811395]

47. Bantum EO, Albright CL, White KK, Berenberg JL, Layi G, Ritter PL, et al. Surviving and thriving with cancer using a web-based health behavior change intervention: randomized controlled trial. J Med Internet Res 2014 Feb 24;16(2):e54 [FREE Full text] [doi: 10.2196/jmir.3020] [Medline: 24566820]

48. Herring SJ, Cruice JF, Bennett GG, Davey A, Foster GD. Using technology to promote postpartum weight loss in urban, low-income mothers: a pilot randomized controlled trial. J Nutr Educ Behav 2014;46(6):610-615 [FREE Full text] [doi: 10.1016/j.jneb.2014.06.002] [Medline: 25069621]

49. Ashton LM, Morgan PJ, Hutchesson MJ, Rollo ME, Collins CE. Feasibility and preliminary efficacy of the 'HEYMAN' healthy lifestyle program for young men: a pilot randomised controlled trial. Nutr J 2017 Jan 13;16(1):2 [FREE Full text] [doi: 10.1186/s12937-017-0227-8] [Medline: 28086890]

50. Valle CG, Tate DF, Mayer DK, Allicock M, Cai J. A randomized trial of a Facebook-based physical activity intervention for young adult cancer survivors. J Cancer Surviv 2013 Sep;7(3):355-368 [FREE Full text] [doi: 10.1007/s11764-013-0279-5] [Medline: 23532799]

51. Mailey E, Huberty J, Irwin B. Feasibility and effectiveness of a web-based physical activity intervention for working mothers. J Phys Act Health 2016 Aug;13(8):822-829. [doi: 10.1123/jpah.2015-0643] [Medline: 26999823]

52. Dadkhah M. Mountain Scholar Home. 2014. Development and Evaluation of the America on the Move Program For University Students URL: https://mountainscholar.org/bitstream/handle/10217/80937/Dadkhah_colostate_0053A_12013. pdf?sequence [accessed 2020-04-27]

53. John WC, Leng H, Kee Y. Use of Facebook in physical activity intervention programme: a test of self-determination theory. Int J Sport Psychol 2015;46(3):210-224. [doi: 10.7352/IJSP.2015.46.210]

54. Duncan M, Vandelanotte C, Kolt GS, Rosenkranz RR, Caperchione CM, George ES, et al. Effectiveness of a web- and mobile phone-based intervention to promote physical activity and healthy eating in middle-aged males: randomized controlled trial of the ManUp study. J Med Internet Res 2014 Jun 12;16(6):e136 [FREE Full text] [doi: 10.2196/jmir.3107] [Medline: 24927299]

55. Looyestyn J, Kernot J, Boshoff K, Maher C. A web-based, social networking beginners' running intervention for adults aged 18 to 50 years delivered via a Facebook group: randomized controlled trial. J Med Internet Res 2018 Feb 26;20(2):e67 [FREE Full text] [doi: 10.2196/jmir.7862] [Medline: 29483065]

56. Ling J, Robbins LB, Zhang N, Kerver JM, Lyons H, Wieber N, et al. Using Facebook in a healthy lifestyle intervention: feasibility and preliminary efficacy. West J Nurs Res 2018 Dec;40(12):1818-1842. [doi: 10.1177/0193945918756870] [Medline: 29421989]

57. Wan ES, Kantorowski A, Homsy D, Teylan M, Kadri R, Richardson CR, et al. Promoting physical activity in COPD: insights from a randomized trial of a web-based intervention and pedometer use. Respir Med 2017 Sep;130:102-110 [FREE Full text] [doi: 10.1016/j.rmed.2017.07.057] [Medline: 29206627]

58. Petrella RJ, Gill DP, Zou G, de Cruz A, Riggin B, Bartol C, et al. Hockey fans in training: a pilot pragmatic randomized controlled trial. Med Sci Sports Exerc 2017 Dec;49(12):2506-2516 [FREE Full text] [doi: 10.1249/MSS.0000000000001380] [Medline: 28719494]

59. Jane M, Hagger M, Foster J, Ho S, Kane R, Pal S. Effects of a weight management program delivered by social media on weight and metabolic syndrome risk factors in overweight and obese adults: a randomised controlled trial. PLoS One 2017;12(6):e0178326 [FREE Full text] [doi: 10.1371/journal.pone.0178326] [Medline: 28575048]

60. Kolt GS, Rosenkranz RR, Vandelanotte C, Caperchione CM, Maeder AJ, Tague R, et al. Using web 2.0 applications to promote health-related physical activity: findings from the WALK 2.0 randomised controlled trial. Br J Sports Med 2017 Oct;51(19):1433-1440 [FREE Full text] [doi: 10.1136/bjsports-2016-096890] [Medline: 28049624] 
61. Maher C, Ferguson M, Vandelanotte C, Plotnikoff R, de Bourdeaudhuij I, Thomas S, et al. A web-based, social networking physical activity intervention for insufficiently active adults delivered via Facebook app: randomized controlled trial. J Med Internet Res 2015 Jul 13;17(7):e174 [FREE Full text] [doi: 10.2196/jmir.4086] [Medline: 26169067]

62. Schaller A, Dintsios C, Icks A, Reibling N, Froboese I. Promoting physical activity in low back pain patients: six months follow-up of a randomised controlled trial comparing a multicomponent intervention with a low intensity intervention. Clin Rehabil 2016 Sep;30(9):865-877 [FREE Full text] [doi: 10.1177/0269215515618730] [Medline: 27496696]

63. Vandelanotte C, Kolt GS, Caperchione CM, Savage TN, Rosenkranz RR, Maeder AJ, et al. Effectiveness of a web 2.0 intervention to increase physical activity in real-world settings: randomized ecological trial. J Med Internet Res 2017 Nov 13;19(11):e390 [FREE Full text] [doi: 10.2196/jmir.8484] [Medline: 29133282]

64. Coffeng JK, Boot CR, Duijts SF, Twisk JW, van Mechelen W, Hendriksen IJ. Effectiveness of a worksite social \& physical environment intervention on need for recovery, physical activity and relaxation; results of a randomized controlled trial. PLoS One 2014;9(12):e114860 [FREE Full text] [doi: 10.1371/journal.pone.0114860] [Medline: 25542039]

65. Willcox J, Wilkinson S, Lappas M, Ball K, Crawford D, McCarthy E, et al. A mobile health intervention promoting healthy gestational weight gain for women entering pregnancy at a high body mass index: the txt4two pilot randomised controlled trial. BJOG 2017 Oct;124(11):1718-1728 [FREE Full text] [doi: 10.1111/1471-0528.14552] [Medline: 28220604]

66. Willis EA, Szabo-Reed AN, Ptomey LT, Steger FL, Honas JJ, Al-Hihi EM, et al. Distance learning strategies for weight management utilizing online social networks versus group phone conference call. Obes Sci Pract 2017 Jun;3(2):134-142 [FREE Full text] [doi: 10.1002/osp4.96] [Medline: 28713582]

67. Lytle LA, Laska MN, Linde JA, Moe SG, Nanney MS, Hannan PJ, et al. Weight-gain reduction among 2-year college students: The CHOICES RCT. Am J Prev Med 2017 Feb;52(2):183-191 [FREE Full text] [doi: 10.1016/j.amepre.2016.10.012] [Medline: 27939237]

68. Gnagnarella P, Misotti AM, Santoro L, Akoumianakis D, del Campo L, de Lorenzo F, et al. Nutritional online information for cancer patients: a randomized trial of an internet communication plus social media intervention. J Cancer Educ 2016 Sep;31(3):472-480. [doi: 10.1007/s13187-015-0820-5] [Medline: 25820605]

69. Turner-McGrievy G, Tate D. Tweets, apps, and pods: results of the 6-month mobile pounds off digitally (mobile POD) randomized weight-loss intervention among adults. J Med Internet Res 2011 Dec 20;13(4):e120 [FREE Full text] [doi: 10.2196/jmir.1841] [Medline: 22186428]

70. Young SD, Cumberland WG, Lee S, Jaganath D, Szekeres G, Coates T. Social networking technologies as an emerging tool for HIV prevention: a cluster randomized trial. Ann Intern Med 2013 Sep 3;159(5):318-324 [FREE Full text] [doi: 10.7326/0003-4819-159-5-201309030-00005] [Medline: 24026317]

71. Young SD, Cumberland WG, Nianogo R, Menacho LA, Galea JT, Coates T. The HOPE social media intervention for global HIV prevention in Peru: a cluster randomised controlled trial. Lancet HIV 2015 Jan;2(1):e27-e32 [FREE Full text] [doi: 10.1016/S2352-3018(14)00006-X] [Medline: 26236767]

72. Washington TA, Applewhite S, Glenn W. Using Facebook as a platform to direct young black men who have sex with men to a video-based HIV testing intervention: a feasibility study. Urban Soc Work 2017;1(1):36-52 [FREE Full text] [doi: 10.1891/2474-8684.1.1.36] [Medline: 29276800]

73. Cheung YT, Chan CH, Lai CJ, Chan WF, Wang MP, Li HC, et al. Using WhatsApp and Facebook online social groups for smoking relapse prevention for recent quitters: a pilot pragmatic cluster randomized controlled trial. J Med Internet Res 2015 Oct 22;17(10):e238 [FREE Full text] [doi: 10.2196/jmir.4829] [Medline: 26494159]

74. Stoddard JL, Augustson EM, Moser RP. Effect of adding a virtual community (bulletin board) to smokefree.gov: randomized controlled trial. J Med Internet Res 2008 Dec 19;10(5):e53 [FREE Full text] [doi: 10.2196/jmir.1124] [Medline: 19097974]

75. Chai W, Zou G, Shi J, Chen W, Gong X, Wei X, et al. Evaluation of the effectiveness of a WHO-5A model based comprehensive tobacco control program among migrant workers in Guangdong, China: a pilot study. BMC Public Health 2018 Feb 27;18(1):296 [FREE Full text] [doi: 10.1186/s12889-018-5182-6] [Medline: 29486753]

76. Graham AL, Cha S, Cobb NK, Fang Y, Niaura RS, Mushro A. Impact of seasonality on recruitment, retention, adherence, and outcomes in a web-based smoking cessation intervention: randomized controlled trial. J Med Internet Res 2013 Nov 7;15(11):e249 [FREE Full text] [doi: 10.2196/jmir.2880] [Medline: 24201304]

77. Graham AL, Cobb NK, Papandonatos GD, Moreno JL, Kang H, Tinkelman DG, et al. A randomized trial of Internet and telephone treatment for smoking cessation. Arch Intern Med 2011 Jan 10;171(1):46-53 [FREE Full text] [doi: 10.1001/archinternmed.2010.451] [Medline: 21220660]

78. Koufopoulos JT, Conner MT, Gardner PH, Kellar I. A web-based and mobile health social support intervention to promote adherence to inhaled asthma medications: randomized controlled trial. J Med Internet Res 2016 Jun 13;18(6):e122 [FREE Full text] [doi: 10.2196/jmir.4963] [Medline: 27298211]

79. Horvath KJ, Oakes JM, Rosser BR, Danilenko G, Vezina H, Amico KR, et al. Feasibility, acceptability and preliminary efficacy of an online peer-to-peer social support ART adherence intervention. AIDS Behav 2013 Jul;17(6):2031-2044 [FREE Full text] [doi: 10.1007/s10461-013-0469-1] [Medline: 23553347]

80. Greene J, Sacks R, Piniewski B, Kil D, Hahn JS. The impact of an online social network with wireless monitoring devices on physical activity and weight loss. J Prim Care Community Health 2013 Jul 1;4(3):189-194. [doi:

10.1177/2150131912469546] [Medline: 23799706] 
81. Herring SJ, Cruice JF, Bennett GG, Darden N, Wallen JJ, Rose MZ, et al. Intervening during and after pregnancy to prevent weight retention among African American women. Prev Med Rep 2017 Sep;7:119-123 [FREE Full text] [doi: 10.1016/j.pmedr.2017.05.015] [Medline: 28660118]

82. Godino JG, Merchant G, Norman GJ, Donohue MC, Marshall SJ, Fowler JH, et al. Using social and mobile tools for weight loss in overweight and obese young adults (project SMART): a 2 year, parallel-group, randomised, controlled trial. Lancet Diabetes Endocrinol 2016 Sep;4(9):747-755 [FREE Full text] [doi: 10.1016/S2213-8587(16)30105-X] [Medline: 27426247]

83. West DS, Monroe CM, Turner-McGrievy G, Sundstrom B, Larsen C, Magradey K, et al. A technology-mediated behavioral weight gain prevention intervention for college students: controlled, quasi-experimental study. J Med Internet Res 2016 Jun 13;18(6):e133 [FREE Full text] [doi: 10.2196/jmir.5474] [Medline: 27296086]

84. Daly N, Farren M, McKeating A, O Kelly R, Stapleton M, Turner MJ. A medically supervised pregnancy exercise intervention in obese women: a randomized controlled trial. Obstet Gynecol 2017 Nov;130(5):1001-1010. [doi:

10.1097/AOG.0000000000002267] [Medline: 29016485]

85. Nam Y. University of Southern California. 2014. The Effect of Twitter Social Support on Health Outcomes and Its Mediators: A Randomized Controlled Trial of a Social Support Intervention on Twitter For Patients Affected by Cancer URL: http:/ lelearnica.ir/start/91cc91ba4de827d935f8c2d174275afa [accessed 2020-04-27]

86. Castillo RC, Wegener ST, Newell MZ, Carlini AR, Bradford AN, Heins SE, et al. Improving outcomes at level I trauma centers: an early evaluation of the trauma survivors network. J Trauma Acute Care Surg 2013 Jun;74(6):1534-1540. [doi: 10.1097/TA.0b013e3182921606] [Medline: 23694884]

87. Morris RR, Schueller SM, Picard RW. Efficacy of a web-based, crowdsourced peer-to-peer cognitive reappraisal platform for depression: randomized controlled trial. J Med Internet Res 2015 Mar 30;17(3):e72 [FREE Full text] [doi: 10.2196/jmir.4167] [Medline: 25835472]

88. Linden K, Sparud-Lundin C, Adolfsson A, Berg M. Well-being and diabetes management in early pregnant women with type 1 diabetes mellitus. Int J Environ Res Public Health 2016 Aug 22;13(8):e836 [FREE Full text] [doi: 10.3390/ijerph13080836] [Medline: 27556476]

89. Cobb NK, Poirier J. Effectiveness of a multimodal online well-being intervention: a randomized controlled trial. Am J Prev Med 2014 Jan;46(1):41-48 [FREE Full text] [doi: 10.1016/j.amepre.2013.08.018] [Medline: 24355670]

90. Namkoong K, Nah S, Record RA, van Stee SK. Communication, reasoning, and planned behaviors: unveiling the effect of interactive communication in an anti-smoking social media campaign. Health Commun 2017 Jan;32(1):41-50. [doi: 10.1080/10410236.2015.1099501] [Medline: 27119592]

91. Bull SS, Levine DK, Black SR, Schmiege SJ, Santelli J. Social media-delivered sexual health intervention: a cluster randomized controlled trial. Am J Prev Med 2012 Nov;43(5):467-474 [FREE Full text] [doi: 10.1016/j.amepre.2012.07.022] [Medline: 23079168]

92. Lau AY, Sintchenko V, Crimmins J, Magrabi F, Gallego B, Coiera E. Impact of a web-based personally controlled health management system on influenza vaccination and health services utilization rates: a randomized controlled trial. J Am Med Inform Assoc 2012;19(5):719-727 [FREE Full text] [doi: 10.1136/amiajnl-2011-000433] [Medline: 22582203]

93. Muntaner-Mas A, Vidal-Conti J, Borràs PA, Ortega FB, Palou P. Effects of a Whatsapp-delivered physical activity intervention to enhance health-related physical fitness components and cardiovascular disease risk factors in older adults. J Sports Med Phys Fitness 2017;57(1-2):90-102. [doi: 10.23736/S0022-4707.16.05918-1] [Medline: 26364690]

94. Owen J, Bantum E, Criswell K, Stanton A. Characterizing patterns of engagement with a socialnetworking intervention to treat cancer-related distress. Asia Pac J Clin Oncol 2012;8(Suppl 3):142-143 [FREE Full text]

95. Sun WH, Wong CK, Wong WC. A peer-led, social media-delivered, safer sex intervention for Chinese college students: randomized controlled trial. J Med Internet Res 2017 Aug 9;19(8):e284 [FREE Full text] [doi: 10.2196/jmir.7403] [Medline: 28793980]

96. Namkoong K, McLaughlin B, Yoo W, Hull SJ, Shah DV, Kim SC, et al. The effects of expression: how providing emotional support online improves cancer patients' coping strategies. J Natl Cancer Inst Monogr 2013 Dec;2013(47):169-174 [FREE Full text] [doi: 10.1093/jncimonographs/lgt033] [Medline: 24395987]

97. George DR, Dellasega C, Whitehead MM, Bordon A. Facebook-based stress management resources for first-year medical students: a multi-method evaluation. Comput Hum Behav 2013 May;29(3):559-562. [doi: 10.1016/j.chb.2012.12.008]

98. Moy ML, Janney AW, Nguyen HQ, Matthess KR, Cohen M, Garshick E, et al. Use of pedometer and internet-mediated walking program in patients with chronic obstructive pulmonary disease. J Rehabil Res Dev 2010;47(5):485-496 [FREE Full text] [doi: 10.1682/jrrd.2009.07.0091] [Medline: 20803392]

99. Bélanger-Gravel A, Godin G, Amireault S. A meta-analytic review of the effect of implementation intentions on physical activity. Health Psychol Rev 2013 Mar;7(1):23-54. [doi: 10.1080/17437199.2011.560095]

100. Fredrix M, McSharry J, Flannery C, Dinneen S, Byrne M. Goal-setting in diabetes self-management: a systematic review and meta-analysis examining content and effectiveness of goal-setting interventions. Psychol Health 2018 Aug;33(8):955-977. [doi: 10.1080/08870446.2018.1432760] [Medline: 29498547]

101. Kadushin C. Understanding Social Networks: Theories, Concepts, and Findings. Oxford, UK: Oxford University Press; 2012. 
102. Southwell BG. Social Networks and Popular Understanding of Science and Health: Sharing Disparities. Baltimore, MD: Johns Hopkins University Press; 2013.

103. Lang T. Advancing global health research through digital technology and sharing data. Science 2011 Feb 11;331(6018):714-717. [doi: 10.1126/science.1199349] [Medline: 21311011]

104. Beran D, Byass P, Gbakima A, Kahn K, Sankoh O, Tollman S, et al. Research capacity building-obligations for global health partners. Lancet Glob Health 2017 Jun;5(6):e567-e568 [FREE Full text] [doi: 10.1016/S2214-109X(17)30180-8] [Medline: 28495256]

105. $\mathrm{Ng} \mathrm{LC}$, Hanlon C, Yimer G, Henderson DC, Fekadu A. Ethics in global health research: the need for balance. Lancet Glob Health 2015 Sep;3(9):e516-e517 [FREE Full text] [doi: 10.1016/S2214-109X(15)00095-9] [Medline: 26275322]

106. Eysenbach G, Consort-eHealth Group. Consort-eHealth: improving and standardizing evaluation reports of web-based and mobile health interventions. J Med Internet Res 2011 Dec 31;13(4):e126 [FREE Full text] [doi: 10.2196/jmir.1923] [Medline: $\underline{22209829]}$

\title{
Abbreviations
}

BCT: behavior change technique

BCTTv1: Behavior Change Technique Taxonomy version 1

MEDLINE: Medical Literature Analysis and Retrieval System Online, or MEDLARS Online

RCT: randomized controlled trials

SWAR: study within a review

WHO: World Health Organization

\author{
Edited by G Eysenbach; submitted 26.08.19; peer-reviewed by S Thiebes, E Gabarron; comments to author 07.10.19; revised version \\ received 26.11.19; accepted 22.03.20; published 11.06 .20 \\ Please cite as: \\ Simeon R, Dewidar O, Trawin J, Duench S, Manson H, Pardo Pardo J, Petkovic J, Hatcher Roberts J, Tugwell P, Yoganathan M, \\ Presseau J, Welch $V$ \\ Behavior Change Techniques Included in Reports of Social Media Interventions for Promoting Health Behaviors in Adults: Content \\ Analysis Within a Systematic Review \\ J Med Internet Res 2020;22(6):e16002 \\ URL: http://www.jmir.org/2020/6/e16002/ \\ doi: $10.2196 / 16002$ \\ PMID: 32525482
}

CRosiane Simeon, Omar Dewidar, Jessica Trawin, Stephanie Duench, Heather Manson, Jordi Pardo Pardo, Jennifer Petkovic, Janet Hatcher Roberts, Peter Tugwell, Manosila Yoganathan, Justin Presseau, Vivian Welch. Originally published in the Journal of Medical Internet Research (http://www.jmir.org), 11.06.2020. This is an open-access article distributed under the terms of the Creative Commons Attribution License (https://creativecommons.org/licenses/by/4.0/), which permits unrestricted use, distribution, and reproduction in any medium, provided the original work, first published in the Journal of Medical Internet Research, is properly cited. The complete bibliographic information, a link to the original publication on http://www.jmir.org/, as well as this copyright and license information must be included. 